\title{
The Current Development Situation, Problems and Countermeasures of Chinese Labor Market
}

\author{
Xinci Zhu \\ Human Resource Management, College of Economic and Management, North China Electric Power University \\ Beinong Road, Huilongguan Town, Changping District, Beijing, China \\ zhuxinci@126.com
}

\begin{abstract}
Under the condition of socialist market economy, labor market has become a new mechanism of allocating labor resources. Through the observation data in recent years, it is not difficult to find that China labor market has many problems. The imbalance between supply and demand, the discrimination phenomenon, the income gap and social security system are not perfect. They all need more attention from government and society. Under the harmfulness of the problem, thinking and countermeasure should be taken into action.
\end{abstract}

Keywords-Labor Market,Labor Supply and Demand,Social Security.

\section{Chinese Labor Market DeVelopment Status} AND PROBLEMS

In 1999, the International Labor Office published "The Main Index System of Labor Market" It recommended 18 indicators and became an important yardstick to measure the labor market. Divided into seven categories, namely, the labor force participation rate, employment, unemployment, education status, salary and cost, productivity and unit cost, poverty and income distribution (2). According to China's national conditions and the status, it is not difficult to see that Chinese labor market still has many problems to be solved.

\section{A. China labor market supply and demand situation}

From age and gender composition differences of labor market, labor supply in China is still mainly concentrated in the young age. Male labor supply is still greater than the female. From the perspective of workers' cultural level, job seekers of high level accounted for $40.2 \%$, junior middle school education and below accounted for $25.6 \%$, college degree or above accounted for 34.1\%. Compared with 2009, job seekers of high school, junior middle school education and below are reduced, the college and above are increased significantly. In fact, since 2003, junior college degree and above in labor market supply shows a rising trend, job seekers' pressure are increased.

Because of the gap between urban and rural income is still greater, labor supply of migrant worker is still huge. According to calculation of the National Bureau, the total of Annual National migrant workers has achieved 229.78 million, including 145.33 million out. Compared with the lat year, it has grown $1.9 \%$. Although migrant workers growth trend has not changed, the quality of them has been improved significantly. Among the migrant workers in 2009, illiteracy accounted for $1.1 \%$, primary culture degree accounted for $10.6 \%$, junior high school education accounted for $64.8 \%$, high school education accounted for $13.1 \%$, technical secondary school and above accounted for $10.4 \%$. The average of high school or above has increased 1.7 percentage points than last year, accounting for $23.5 \%{ }^{3}$.

With the growth of Chinese GDP, the amount of labor demand increases. Labor's quality also in the request yet. The employer requires the high level education demand occupies 39.5\% among all the requirement. Demand in the proportion of the second industry increased, and the proportion of the third industry decreased. We can see the gap clearly through the employment contrast in different industry proportion between China and other countries. (Refer to Figure 1)

\begin{tabular}{|l|l|l|l|l|l|l|}
\hline \multirow{2}{*}{ Country } & \multicolumn{2}{|l|}{ Primary Industry } & \multicolumn{2}{l|}{ Secondary Industry } & \multicolumn{2}{l|}{ Third Industry } \\
\cline { 2 - 8 } & 2005 & 2010 & 2005 & 2010 & 2005 & 2010 \\
\hline China & 44.8 & 36.7 & 23.8 & 28.7 & 31.4 & 34.6 \\
\hline Macau & 0.1 & & 25.0 & 16.0 & 74.7 & 84.0 \\
\hline India & 55.8 & 51.1 & 19.0 & 22.4 & 25.2 & 26.6 \\
\hline
\end{tabular}




\begin{tabular}{|l|l|l|l|l|l|l|} 
Israel & 2.0 & 1.7 & 21.4 & 20.4 & 75.7 & 77.1 \\
\hline Japan & 4.4 & 3.7 & 27.9 & 25.3 & 66.4 & 69.7 \\
\hline Korea & 7.9 & 6.6 & 26.8 & 17.0 & 65.2 & 76.4 \\
\hline America & 1.6 & 1.6 & 20.6 & 16.7 & 77.8 & 81.2 \\
\hline Italy & 4.2 & 3.8 & 30.8 & 28.8 & 65.0 & 67.5 \\
\hline England & 1.3 & 1.2 & 22.2 & 19.1 & 76.3 & 78.9 \\
\hline
\end{tabular}

Figure 1. Grouped by three industry composition of the working population Unit: \%

\section{B. Discrimination in Chinese labor market}

From the supply of labor of sex and age differences, China's labor market exists discrimination. The so-called labor market discrimination, referring to certain employees who provides the same productivity. Due to some non economic individual of different characteristics such as age, gender, nationality, religion, below the name, origin, appearance, received unequal treatment in the recruitment and remuneration, etc. According to the information statistical data of part of our country city occupation labor market's supply and demand, job seekers between age 16-34 in 2010 is the main body in the market, $75.4 \%$ among the total number, age 16-24 job seekers accounted for $39.9 \%$, age $25-34$ job seekers accounted for $35.5 \%$. The number of male job seekers is more than female, the proportion is $54.4 \%$ and $45.6 \%$ respectively. Compared China and USA practically, the gap is very big. "Bill of rights" provisions of chapter seventh, employers can not discriminate employees, because of race, color, descent, religion, gender; "Employ Age" prohibit discriminate the people over 40. Although China has promulgated the "The labor law of the people's Republic of China" in July 5, 1994 , the binding effect is remarkable.

\section{Chinese market labor income gap}

Along with our country's economy development, the income of rural residents also continued to rise, but the income gap between urban and rural areas still exists. Jointly issued by the rural development research Chinese Academy of Social Sciences, the National Bureau of statistics of rural social and Economic Investigation Division and social science document pressed the "The Green Book Rural Economy" in 2011 shows: In 2012, the national rural residents income grows faster than in the cities for the first time since 1998. Compared with the previous year, the urban rural income gap decreased, but the income gap is still huge ${ }^{\circledR}$. It has been reported that, "The industry income gap in China is 15 times". The financial industry, information industry and scientific research are of the first three major categories of industry incomes. Agriculture, forest, animal husbandry, fishery in this category is the minimum industry of the average wage.

\section{EXPLORE THE REASONS FOR CHINESE LABOR PROBLEMS}

The problems of Chinese labor market problems are relevant to outside factors and conditions and historical development. On the labor supply and demand point of view, the current nine year compulsory education universal, and family planning policy, due to the only one child family make every effort to develop high-end proportion of labor force. And some rural areas do not comply with the policy, they still have many children. In the selection of education opportunities, they often give the boy more opportunities. This eventually formed the difference of labor quality in urban and rural areas, and the structure of supply and demand contradiction. From the labor market discrimination, although the "Labor Law" and "Labor Contract Law" for discrimination has been clearly defined, some companies still tried many ways to achieve discrimination. For example, in the article twelfth of "Labor Law" , it stipulates that the employment of laborers should not be discriminated by ethnic, racial, gender, religious belief. However, because of the supervision mechanism of China is not very perfect, even if the enterprise has inappropriate behavior, the public can do nothing. By contrast, the United States has a strong supervision mechanism, in chapter seventh of "The Bill of Rights", it provisions to establish the Equal Employment Opportunity Commission (EEOC), investigate discrimination and represents the petitioners sued; federal contract execution plan office: a business of enterprises to assume more obligations and government anti discrimination: get rid of age discrimination and disability discrimination obligation.

The reason of the income gap between the industry mainly lies in the part of the industry monopoly position, rather than the natural difference between the full market competition of industries. The improvement of the transfer number and average wage level of rural labor force is the main factor of the farmer income growth. The imperfect social security system is due the development of China. To establish the perfect social security system, should spend a lot of manpower and material resources, China are unable to balance the difference between urban and rural. However, with the development of Chinese economy, it will 
eventually goes away.

\section{CHINESE ACHIEVEMENT}

The economic base determines the superstructure. When China's level of economic development achieved a certain stage, China began to introduce the corresponding legal protection to labor it. The issue of "Labor Law" and perfection of "Labor Contract Law", they specified from the employee rights and employer obligations. This largely ensured the workers' wages level, rest and vacation time, equal employment rights, welfare and insurance.

\section{Suggestions To Solve The Problem Of Chinese LABOR MARKET}

\section{A. Perfect the labor legislation and supervision mechanism}

Although labor legislation has been achieved, many enterprises take advantage of loopholes in a law. The problems that may arise should be considered in the next revision, making the law more perfect, to truly protect workers and the order of the labor market effect.

Supervision mechanism of our country is not perfect, especially the trade unions. Not like western countries, China Union just empty the table. It can not really serve for the labor, can not solve the contradiction. And even when some enterprises recruiting new employees, it clearly hinted to forbid joining the union. So how to guarantee the whole labor market?

\section{$B$. To promote the healthy and sustainable development of population, economy}

China should relax the population policy to respond to future labor demand. Population policy adjustments not only can alleviate the problem of insufficient for future labor supply effectively, it also can alleviate the aging problem which is becoming more and more serious. To develop the science and technology, speed up technological innovation and transformation, accelerate innovation, improve labor productivity. It is the objective requirement of the transformation of economic development mode on the one hand, and sustainable development of resources and environment on the other hand.

\section{CONCLUSION}

Because of China's special national conditions, the labor market is improving step by step from central planning to market economy. Although the government and the public are making unremitting efforts, there still have a variety of problems in China's labor market. When people can not aware of adverse effects brought about by these problems, both sides of labor and capital will continue to employ this form of development. It will influence economic and labor market of China inevitably. From the government's view, it should use legal policy to restraint the main parties' act, prohibiting things which completely out of line. Personally, we should find problems. We can not along its development and should kill them before the problem has qualitative changed.

\section{REFERENCES}

[1] Huang Anyu: "The Economic Transformation in the Labor Market", Shanghai people's publishing house, 2010 edition, page sixth.

[2] Huang Anyu: "The Economic Transformation in the Labor Market", Shanghai people's publishing house in 2010 edition, page 367th.

[3] The Yang Heqing and $\mathrm{Li} \mathrm{Xu:} \mathrm{"The} \mathrm{Blue} \mathrm{Book} \mathrm{of} \mathrm{China} \mathrm{labor}$ economic", labor and social security press in 2012 edition, page 5-14.

[4] Yang Heqing and Li Xu: "The Blue Book of China labor economic", labor and social security press in 2012 edition, page 145th. 